\title{
Effect of Waste Heat Recovery System on Performance and Emission Characteristics of Spark Ignition (SI) Engine Fuelled with Neat Ethanol (E100)
}

\author{
S.Gowthaman ${ }^{a^{*}}$, Gobikrishnan $\mathbf{U}^{\mathrm{b}}$ \\ ${ }^{a^{*}}$ Associate Professor, ${ }^{b}$ Assistant Professor \\ ${ }^{a}$ Department of Automobile Engineering, ${ }^{b}$ Department of Mechanical Engineering \\ ${ }^{a}$ Kalasalingam Academy of Research and Education, ${ }^{b}$ Sona College of Technology \\ Tamilnadu, India. gowthammech@hotmail.com
}

\begin{abstract}
The SI engine could not be operated efficiently with neat ethanol fuel due to its high self ignition temperature and latent heat of vaporization compared with petrol. The above issues of SI engine is turned to be an objective of this study, where the SI engine was operated with neat ethanol fuel under different inlet air temperatures. The result of this study is indicated that the neat ethanol fuel could be utilized efficiently in SI engine with waste heat recovery system. The specific fuel consumption (SFC) of SI engine has decreased with neat ethanol fuel compared with petrol fuelled engine. It is also found that the SI engine has registered almost same brake thermal efficiency (BTE) values with neat ethanol compared to petrol. The exhaust emissions such as carbon monoxide (CO) and Hydrocarbon ( $\mathrm{HC})$ were reduced in SI engine, at the same time there was an increase in oxide of nitrogen (NOx).
\end{abstract}

Keywords: Spark Ignition Engine, Ethanol fuel, Waste Heat Recovery System, Preheating, Reduction of Pollutions.

\section{INTRODUCTION}

Ethanol is one of the suitable alternative fuels for spark ignition (SI) engine and it can be used without changing any modification in the engine. The ethanol fuelled SI engine has emitted low $\mathrm{CO}$ and $\mathrm{HC}$ emission without affecting the engine efficiency [1-4]. Most of the studies resulted that ethanol is more efficient in SI engine, when it is blended with petrol and emitted lower pollutants compared to neat ethanol fuelled engine. The properties of ethanol fuel is almost similar to petrol except latent heat of vaporization and self-ignition temperature. It made the ethanol more complex to use as neat fuel in spark ignition engine. The ethanol fuels are renewable and it can be extracted from bio-waste such as sugar cane, crop waste, fruits and vegetable waste. India is the second topmost country producing the ethanol.

The availability of ethanol in India willfulfil the fuel need for automobile in the future. There are many research being conducted on SI engine to operate efficiently with ethanol fuel and also analyse the methods to be overcome the issues of high latent heat of vaporization and self-ignition temperature of ethanol. From the existing studies it was found that the following methods such as blending with petrol, exhaust gas recirculation (EGR), inlet air preheating and fumigation are the effective methods to utilize the ethanol in SI engine [5-8].

There are more number of studies have done on fossil fuel and ethanol blends in SI engine. The performance and emission characteristics of petrol / ethanol fuelled SI engine was studied by Yusoff, M.N. A. M., et al. [9]. The authors done their work on four-cylinder spark ignition engine and conducted the experiment with E10 and E20 blends by varying the engine parameters like speeds and torque. From the result, it was observed that the engine has produced more torque and thermal efficiency while operating with E20 blend.The result of this study proved that the addition of ethanol in the blend has improved engine performance. The similar kind of study had done by Phuangwongtrakul S et al. [10] on SI engine with different ethanol-gasoline blends. He conducted the experiments with E10, E20, E30, E40, E50, E60, E70, E85, and E100 and absorbed the performance and emission characteristics. The results indicated that an increasing of ethanol ratio in the blend has improved engine torque, especially at low engine speed.

Yaman Het al. [11] done their experimentation in a single cylinder four stroke SI engine to analyse the performance and emission characteristics with different ethanol-gasoline blends as E0, E10, E20 and E30. The engine was operated efficiently with different ethanol blends and found the reductions of carbon monoxide $(\mathrm{CO})$, carbon dioxide $\left(\mathrm{CO}_{2}\right)$ and nitrogen oxide $\left(\mathrm{NO}_{\mathrm{X}}\right)$ emissions without affecting the engine power. The methods of ethanol injection in SI engine makes significant impact on performance and emission characteristics. The port injection system normally gives enough time to the fuel to mix with air and form stoichiometric mixture before stating the combustion process. From the many experiments, it was found that the port injected ethanol fuel has resulted low $\mathrm{CO}$ and $\mathrm{HC}$ emissions with 
significant improvement in the thermal efficiency $[12,13]$. Kim Net al [14] studied the combustion and emission characteristics of an SI engine with ethanol port injection system. The results indicated that ethanol injection can be reduced the knock frequency and there was a reduction in particulate emission.

The performance, emission and combustion behaviour of ethanol fuelled SI engine has varied based on injection systems. Cohn et al. [15] conducted the experiment on direct injected spark ignition engine with different ethanol blends. The experimental investigations were carried out by varying the engine load with constant engine speed. From the experimental result, it was concluded that the engine was consumed minimum amount of fuel, when it operated with high ethanol blends. Stein et al. [16] compared the performance and emission characteristics of ethanol fuelled engines having different injection systems such as DI and PFI systems. From the result, it was found that DI with E85 engine has given better results compared to PFI engine. There are many reasons for increasing engine efficiency with direct injection system, air turbulence and high injection pressure allow ethanol to mix properly with air and it shorten the combustion duration. Zhuang et al. [17] is also done his work on SI engine with ethanol fuel, the author investigated the effect of DI on engine fuel consumption (FC), combustion and emission characteristics. The experimental was conducted in single cylinder, four stroke spark ignition engine. During the experimentation, the engine was allowed to operate with different petrol ethanol blends. From the result, it was observed that the volumetric efficiency of the engine is increased due to the enhanced charge cooling effect and the rate of fuel consumed by the engine was being increased, if increasing the percentage of ethanol in the blends. The exhaust pollutants such as $\mathrm{HC}$ and $\mathrm{CO}$ emissions were drastically decreased due to availability of oxygen and high octane number of fuel.

Most of the studies on ethanol with spark ignition engine have done by varying the injection methods, blend with petrol and changing the operating parameters of spark ignition engine like compression ratio, injection timing and adopting EGR. Meanwhile some of other studies have done with neat ethanol fuel in SI engine. This study investigate the performance and emission characteristics of neat ethanol fuel in spark ignition engine with waste heat recovery systems, Where the inlet air has to be preheated with engine exhaust gas. The experimental investigation will be conducted with different inlet air temperature such as $50^{\circ} \mathrm{C}, 52^{\circ} \mathrm{C}, 54^{\circ} \mathrm{C}, 56^{\circ} \mathrm{C}, 58^{\circ} \mathrm{C}$ and $60^{\circ} \mathrm{C}$ and identify the optimum air temperature for effective utilization of neat ethanol.

\section{FUEL PROPERTIES}

Ethanol is the suitable alternative fuel for spark ignition engine, the properties of ethanol is almost similar to the petrol except latent heat of vaporization and selfignition temperature. The properties of ethanol and petrol are compared in the table 2.1. In general, ethanol has some oxygen molecules, it is around $34.7 \%$. The ethanol fuel has high octane value compared to petrol and it favours for high anti knocking characteristics and creates more heat power during the combustion.

Table 2.1: Properties of Fuels

\begin{tabular}{|l|c|c|}
\hline \multicolumn{1}{|c|}{ Properties } & Petrol & Ethanol \\
\hline Carbon content \% & 86 & 52.2 \\
\hline Hydrogen content\% & 14 & 13.1 \\
\hline Oxygen content\% & 0 & 34.7 \\
\hline Freezing point & -60 & -114 \\
\hline Boiling point & 85 & 78 \\
\hline Latent heat of vaporization $(\mathrm{KJ} / \mathrm{Kg})$ & 461 & 904 \\
\hline Octane number & 87 & 108.6 \\
\hline Auto ignition temperature & 280 & 420 \\
\hline Calorific value $(\mathrm{KJ} / \mathrm{Kg})$ & 45000 & 29300 \\
\hline Stoichiometric air/fuel ratio & $14.7: 1$ & $9: 1$ \\
\hline Density $\left(\mathrm{Kg} / \mathrm{m}^{3}\right)$ & 0.742 & 0.79 \\
\hline
\end{tabular}

\section{EXPERIMENTAL SETUP AND PROCEDURE}

The line diagram of the experimental setup is shown in figure 3.1. The experimental investigation was conducted in a single-cylinder, four-stroke SI, air cooled engine. The specification of the engine is listed in the table3.1. For the experimentation, the two-wheeler silencer was slightly modified to extract the waste heat from the exhaust gas. Where the fresh inlet air is allowed to flow through the modified silencer and it carries some amount of heat energy to preheat the ethanol. These preheated ethanol will be created as homogeneous mixture before stating the combustion process. The properties of both ethanol and petrol fuels are listed in table2.1.

\section{Table 3.1: Engine Specification}

\begin{tabular}{|c|c|c|}
\hline S.No & \multicolumn{2}{|c|}{ Engine specification } \\
\hline 1. & Engine Type & $\begin{array}{l}\text { Air Cooled, } 4 \text { Stroke, } \\
\text { SI Engine }\end{array}$ \\
\hline 2. & No. of Cylinders & 1 \\
\hline 3. & Max Power & 10.30 PS @ 7500 rpm \\
\hline 4. & Max Torque & $\begin{array}{l}10.30 \mathrm{Nm} @ 5500 \\
\mathrm{rpm}\end{array}$ \\
\hline 5. & Displacement & $124.73 \mathrm{cc}$ \\
\hline 6. & Cooling System & Air Cooled \\
\hline 7. & Gear Box & 4 Speed \\
\hline 8. & Bore & $52.4 \mathrm{~mm}$ \\
\hline 9. & Stroke & $57.8 \mathrm{~mm}$ \\
\hline 10. & Max Speed & $93 \mathrm{kmph}$ \\
\hline
\end{tabular}

The line diagram of designed silencer is shown figure 3.2. It contains two air flow controller, one of the controller is placed at exhaust pipe to control the flow of exhaust gas to the regenerative chamber to preheat the fresh air and next one is fixed at the engine inlet side to control the temperature of air admitted to the engine by mixing of atmosphere air. The flow controllers are controlled manually and it is used to change the temperature of preheated air for the experimentation. The temperature of preheated air is measured by the thermocouple placed at engine inlet pipe. The use of both flow controller and thermocouple, the temperature of inlet air is varied as $50^{\circ} \mathrm{C}, 52^{\circ} \mathrm{C}, 54^{\circ} \mathrm{C}, 56^{\circ} \mathrm{C}, 58^{\circ} \mathrm{C}$ and $60^{\circ} \mathrm{C}$ and the experimentation was conducted. 


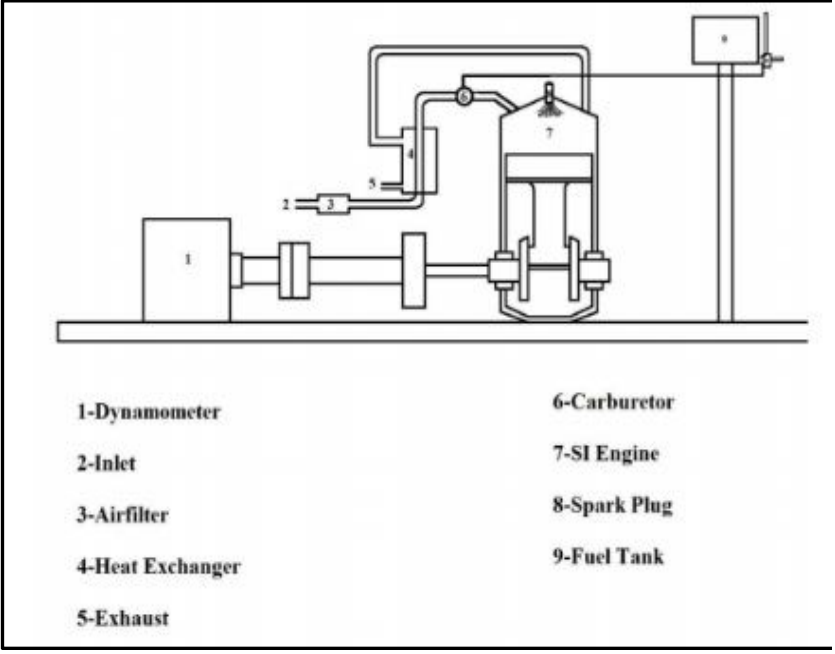

Fig 3.1: Experimental Setup

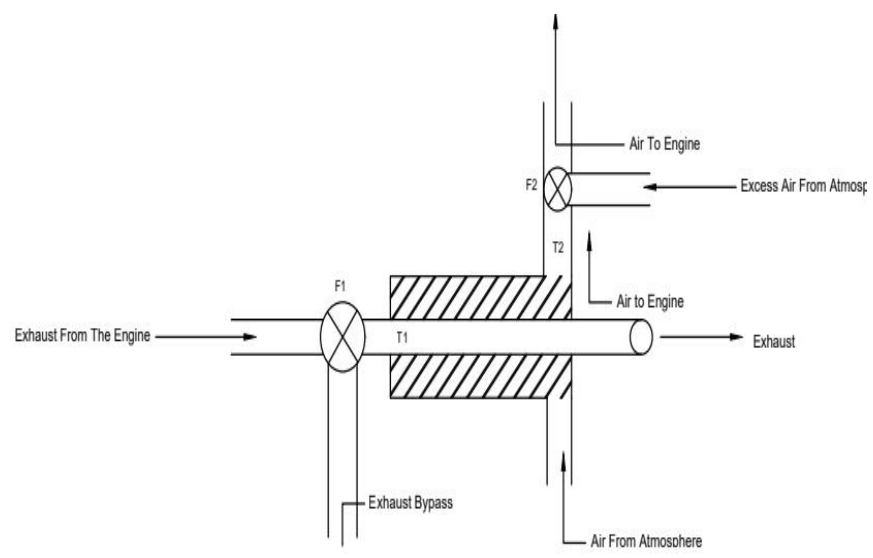

Fig 3.2: Setup of Waste Heat Recovery

During the experimentation, the ethanol fuel was mixed with air in the carburettor. The preheated air passes through the carburettor, where the injected ethanol observed the heat from the air and got vaporized. At suction stroke, the air-fuel mixture enters to engine as partially homogeneous and in the second stroke of compression, the whole mixture turned to be completely homogeneous due to the compression of piston.

\section{RESULT AND DISCUSSION}

The petrol engines are more efficient than diesel engine due to its cleaner combustion. The SI engines are operated with homogeneous mixture for all mode of operations. The specific fuel consumption (SFC) of the engine is calculated by the rate of combustion. That is amount of heat liberate by the fuel when it has combust. The figure 4.1 shows the variation SFC values with engine speed for different inlet air temperatures such as $50^{\circ} \mathrm{C}, 52^{\circ} \mathrm{C}, 54^{\circ} \mathrm{C}, 56^{\circ} \mathrm{C}, 58^{\circ} \mathrm{C}$ and $60^{\circ} \mathrm{C}$. From the figure, it was found that the SFC values are continuously decreasing with increasing preheating temperature.

From the result of this experiment, it was found that the SI engine was operated efficiently at $56^{\circ} \mathrm{C}$ and $58^{\circ} \mathrm{C}$ air temperatures. The SI engine was operated with lower SFC values at $56^{\circ} \mathrm{C}$ and $58^{\circ} \mathrm{C}$ air temperatures for different engine speed conditions. During the experimentation the SI engine was operated with different speeds such as $1000 \mathrm{rpm}, 2000 \mathrm{rpm}, 3000 \mathrm{rpm}, 4000 \mathrm{rpm}$, $5000 \mathrm{rpm}$ and $6000 \mathrm{rpm}$. Meantime the rate of fuel consumed by the engine was calculate by the stop watch.

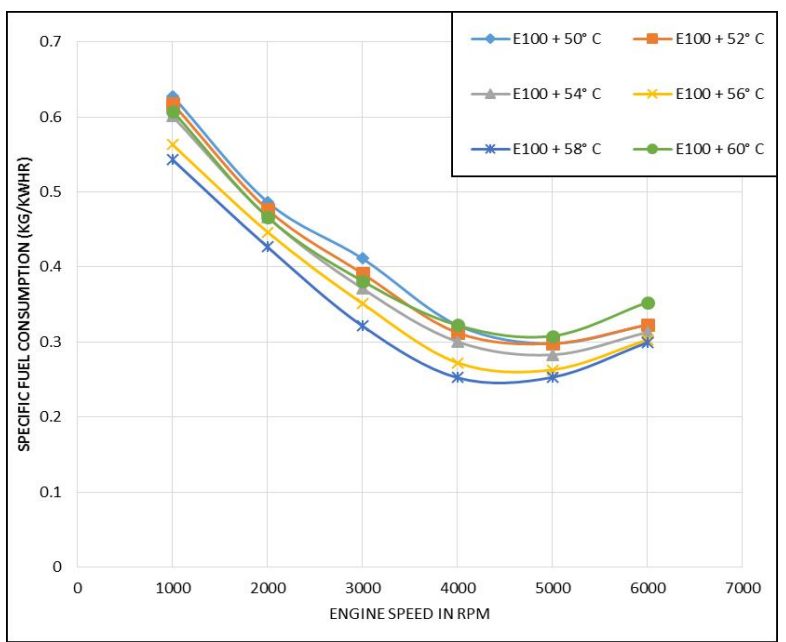

Fig 4.1: Variation in SFC with Engine Speed

From the result, it was understood that the preheated air vaporize the ethanol fuel and it makes the mixture as homogeneous in SI engine before occurring the combustion process. In addition, increasing preheating temperature reduces the pollutions such as Carbon monoxide (CO) and Hydrocarbon (HC).

The variation in brake thermal efficiency (BTE) with engine speed of SI engine is shown in figure 4.2. The brake thermal efficiency of SI engine could be calculated by the amount of heat liberate by the specific amount of fuel. The SI engine has high BTE compared to diesel engine due to it cleaner combustion. In this study, the SI engine was operated with neat ethanol fuel with the help of air preheating system. The result of this study has proved that ethanol was an effective alternate fuel for SI engine and it could be controller by the air preheating system. The above graph indicated that the brake thermal efficiency of ethanol fuelled SI engine was increasing with increasing air temperature.

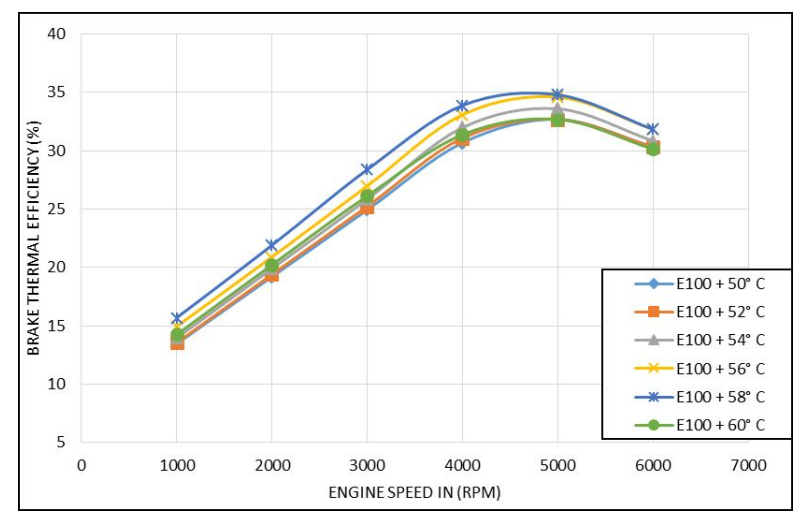

Fig 4.2: Variation in Brake Thermal Efficiency with Engine Speed

From the experimental result, it was observed that the SI engine has lower brake thermal efficiency at lower speed and it has been increasing with engine speed. In 
addition, the engine has produced higher thermal efficiency during the speed of $4000 \mathrm{rpm}$ to $5000 \mathrm{rpm}$. From the result, it was found that the SI engine has registered high thermal efficiency at $56^{\circ} \mathrm{C}$ and $58^{\circ} \mathrm{C}$ air temperatures.

The oxides of nitrogen (NOx) is one of the harmful pollutants emitted by the SI engine. The reason for NOx formation in SI engine is high combustion temperature. In general, the SI engines are operated with homogenous air-fuel mixture and it create high combustion temperature. It cause more NOx formation in SI engine, these NOx emissions create impact on environment and living beings as well. From the result of this experiments, it is found that the ethanol fuelled SI engine has produced high NOx emission. In addition, the NOx formation is increased with increasing engine speed and air temperature.

The figure 4.3 shows the variation in NOx emission with different engine speed and air temperature of ethanol fuelled SI engine. The NOx emission is increased with increasing engine speed, the reason is high engine speed increases combustion temperature. If the combustion temperature is reached beyond the 1500 degree centigrade. It starts to create NOx emission in the SI engine. From the result it was observed that the increasing preheating temperature of air increasing combustion temperature and NOx emission as well.

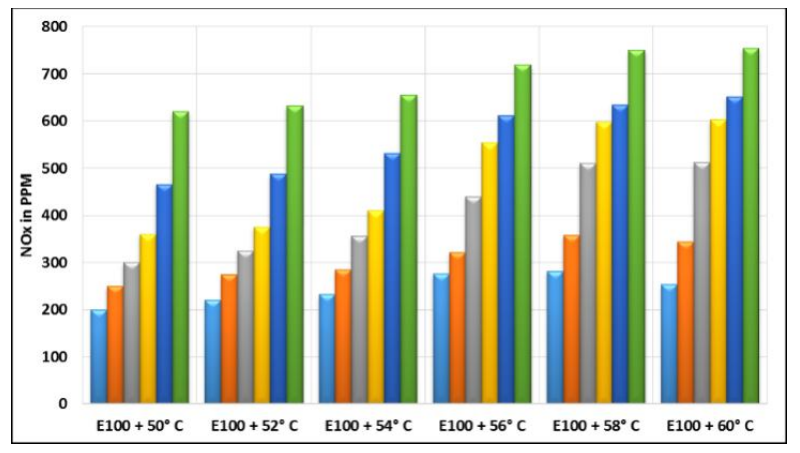

Fig 4.3: Variation in NOx with Engine Speed

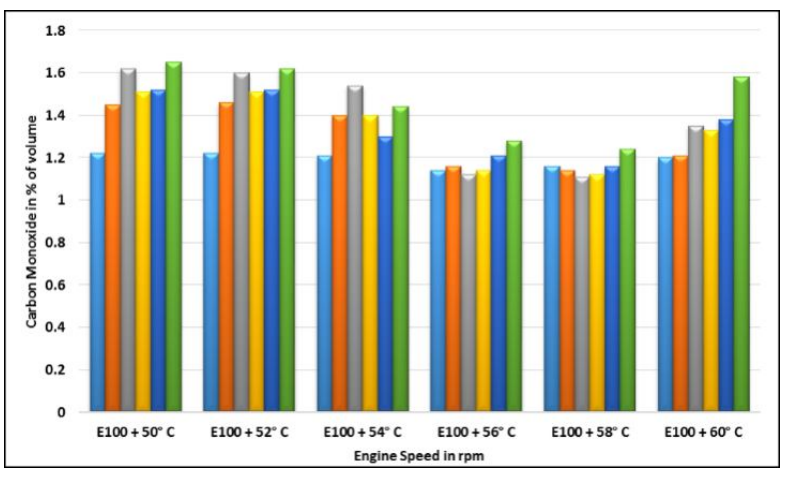

Fig 4.4: Variation in CO with Engine Speed

The Carbon monoxide (CO) is the emission created by the SI engine due to incomplete combustion and it might be lead due to cold starting and low combustion temeorature. The $\mathrm{CO}$ is the intermediate product, it can be formed due to lagging of oxygen in the cylinder. The figure 4.4 shows the variation in $\mathrm{CO}$ emission with engine speed and air temperature. Where the engine was operated with different speed and preheating temperatures. From the graph, it is observed that the SI engine has emitted high $\mathrm{CO}$ emissions at lower and higher speed and it has lower $\mathrm{CO}$ emission in the average speeds. The ethanol fuelled SI engine has regestered low $\mathrm{CO}$ emission at $56^{\circ} \mathrm{C}$ and $58^{\circ} \mathrm{C}$ preheating temperature.

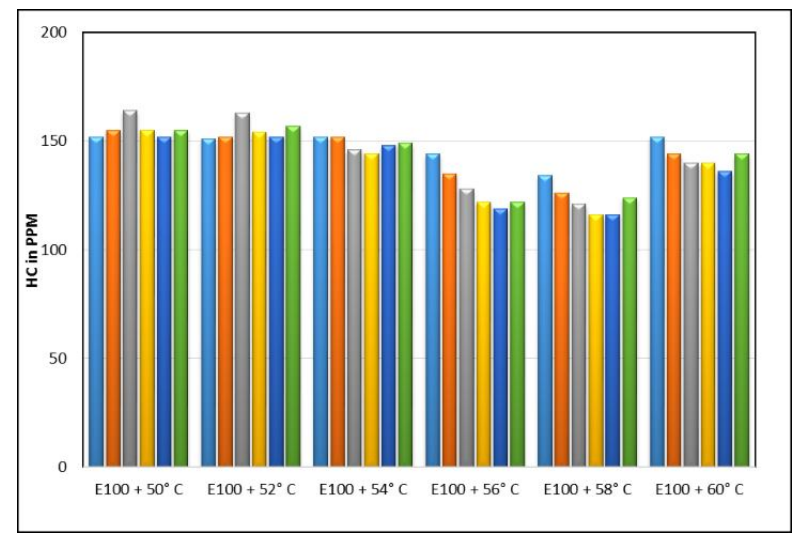

Fig 4.5: Variation in $\mathrm{HC}$ with Engine Speed

Hydrocarbon (HC) is the harmful emission created in the SI engine due to incomplete combustion. The variation in $\mathrm{HC}$ with engine speed and preheating temperature are shown in figure 4.5. It is found that the SI engine has emitted high $\mathrm{HC}$ emissions at the time of starting and higher speed. In addition, it is also found that the $\mathrm{HC}$ emission in SI engine has reduced with increasing the air temperature. The preheating temperature about $56^{\circ} \mathrm{C}$ and $58^{\circ} \mathrm{C}$ operated SI engine has low $\mathrm{HC}$ emissions compared to other air temperate.

\section{CONCLUSION}

From this study, it was proved that ethanol has an efficient alternative fuel for spark ignition engine. The neat ethanol fuel could be used in spark ignition engine with waste heat recovery system. The following points were conclude from this experimental investigation,

$\checkmark \quad$ Specific fuel consumption of SI engine was decreased with increasing inlet air temperature. The preheating temperature $56^{\circ} \mathrm{C}$ and $58{ }^{\circ} \mathrm{C}$ operated SI engine has registered lower specific fuel consumption values.

$\checkmark \quad$ Brake thermal efficiency of SI engine was increased with increasing engine speed and preheating temperature. The SI engine has registered higher BTE at $4000 \mathrm{rpm}$ and $5000 \mathrm{rpm}$.

$\checkmark \quad$ The SI engine has emitted high NOx emission with ethanol fuel. The rate of NOx emission in SI engine was increased with increasing speed and preheating temperature. The air temperature $60^{\circ} \mathrm{C}$ operated SI engine has registered high NOx values compared to other temperatures.

$\checkmark$ Carbon monoxide emissions were created due to incomplete combustion of the charge. The ethanol fuelled SI engine has higher $\mathrm{CO}$ emissions at low and high speed conditions. At average speed conditions, the SI engine has emitted low $\mathrm{CO}$ emission due to complete combustion of ethanol fuel.

$\checkmark$ The SI engine has emitted lower hydrocarbon emissions for various engine speed. It has been further decreased with increasing the air preheating 
temperature. The air temperature such as $56^{\circ} \mathrm{C}$ and 58

${ }^{\circ} \mathrm{C}$ operated SI engine has low $\mathrm{HC}$ emissions.

\section{REFERENCES}

1. Altın İ, Bilgin A. A parametric study on the performance parameters of a twin-spark SI engine. Energy Convers Manage 2009;50(8):1902-7.

2. Altin İ, Sezer İ, Bilgin A. Effects of the stroke/bore ratio on the performance parameters of a dualspark-ignition (DSI) engine. Energy Fuels 2008;23(4):1825-31.

3. Altın İ, Bilgin A. Quasi-dimensional modeling of a fast-burn combustion dual-plug spark-ignition engine with complex combustion chamber geometries. ApplThermEng 2015;87:678-87.

4. Bozza F, Gimelli A, Siano D, Torella E, Mastrangelo G. A quasi-dimensional threezone model for performance and combustion noise evaluation of a twin-spark high-EGR engine. SAE Trans 2004:491501.

5. Migita H, Amemiya T, Yokoo K, lizuka Y. The new 1.3-liter 2-plug engine for the 2002 Honda Fit. JSAE Rev 2002;23(4):507-11.

6. Heywood JB. Internal combustion engine fundamentals. New York: McGraw-Hill;1988.

7. Kuroda H, Nakajima Y, Sugihara K, Takagi Y, Muranaka S. The fast burn with heavyEGR, new approach for low NO $x$ and improved fuel economy. SAE Trans 1978:1-15.

8. Mattavi JN. The attributes of fast burning rates in engines. SAE Trans1980:2783-801.

9. Yusoff M, Zulkifli NWM, Masjuki HH, Comparative assessment of ethanol and isobutanol addition in gasoline on engine performance and exhaust emissions. J Clean Prod 2018;190:483-95.

10. Phuangwongtrakul S,Wechsatol W, Sethaput T,Experimental study on sparking ignition engine performance for optimal mixing ratio of ethanolegasoline blended fuels. ApplThermEng 2016;100:869-79.

11. Dogan B, Erol D, Yaman H,The effect of ethanolgasoline blends on performance and exhaust emissions of a spark ignition engine through energy analysis. ApplThermEng 2017;120:433-43.

12. Huang $Y$, Hong G. Investigation of the effect of heated ethanol fuel on combustion and emissions of an ethanol direct injection plus gasoline port injection (EDIp GPI) engine. Energy Convers Manag 2016;123:338-47.

13. CatapanoF, Di Iorio S, Sementa P.Investigation of ethanol-gasoline dual fuel combustion on the performance and exhaust emissions of a small SI engine[R]. SAE Technical Paper. 2014.

14. Kim J, Chun KM, Song S, The effects of hydrogen on the combustion, performance and emissions of a turbo gasoline direct-injection engine with exhaust gas recirculation.Int $\mathrm{J}$ Hydrogen Energy 2017;42(39):25074-87.

15. Cohn D, Bromberg L, Heywood J. Direct Injection Ethanol Boosted Gasoline Engines:Biofuel Leveraging For Cost Effective Reduction of Oil Dependence and CO2Emissions. 2015.

16. Stein RA, House CJ, Leone TG. Optimal use of E85 in a turbocharged direct injection engine. SAE Int $\mathrm{J}$ Fuels Lubr 2009;2:670-82.
17. Zhuang Y, Hong G. The effect of direct injection timing and pressure on engine performance in an ethanol direct injection plus gasoline port injection (EDI+ GPI) SI engine. SAE Technical Paper; 2013. 